\title{
$O$ antigo constitucionalismo na história hispano-americana do século XIX
}

\author{
The ancient constitutionalism in 19th century Hispanic-American history
}

José Carlos Chiaramonte**

\section{REFERÊNCIA}

CHIARAMONTE, José Carlos. O antigo constitucionalismo na história hispano-americana do século XIX. Revista da Faculdade de Direito da UFRGS, Porto Alegre, n. 44, p. 154-181, dez. 2020. DOI: https://doi.org/10.22456/0104-6594.109643.

\begin{abstract}
RESUMO
O predominante critério de que o constitucionalismo hispano-americano começa com os primeiros textos constitucionais escritos resultou em ocultar a existência de pautas constitucionais antigas que regiam as sociedades hispano-americanas antes e depois de suas independências. $\mathrm{O}$ peso do velho esquema da predominância de um caudilhismo anárquico e o feito de que o termo "constituição" esteja demasiado associado aos textos escritos que conhecemos atualmente, parece dificultar a compreensão da existência de constituições não escritas - que, na realidade, geralmente eram reunião de pautas consuetudinárias e de textos escritos. O certo é que as sociedades hispano-americanas, como as anglo-americanas e as europeias, possuíam então normas constitucionais geralmente invocadas com o enunciado "antiga constituição" ou "leis fundamentais".
\end{abstract}

\section{PALAVRAS-CHAVE}

Constitucionalismo hispano-americano. Antiga Constituição. Caudilhismo anárquico.

\begin{abstract}
The predominant criteria that Hispanic-American constitutionalism begins with early written constitutional texts has obscured the existence of ancient constitutional guidelines governing Hispanic-American societies before and after their independences. The weight of the old scheme of the predominance of an anarchic caudillismo and the fact that the term constitution is strongly associated with the written texts we know today, seems to difficult the recognition of the existence of unwritten constitutions - which, usually consisted in a collection of customary guidelines and written texts. The truth is that Hispanic-American societies, such as Anglo American and European societies, possessed at that time constitutional norms generally invoked with the statements "ancient constitution" or "fundamental laws.".
\end{abstract}

\footnotetext{
* Texto original em língua espanhola: CHIARAMONTE, José Carlos. El antiguo constitucionalismo en la historia hispanoamericana del siglo XIX. Nuevo Mundo, Mundos Nuevos. Débats, 08 out. 2020. Disponível em: http://journals.openedition.org/nuevomundo/81983; DOI: https://doi.org/10.4000/nuevomundo.81983. Tradução para a língua portuguesa por Henrique Montagner Fernandes (Doutor em História do Direito pelo PPGDirUFRGS). Revisão da tradução por Alfredo de J. Flores (Prof. Permanente no PPGDir-UFRGS).

** Professor Honorário da Universidad de Buenos Aires (UBA, Argentina). Investigador Emérito do Consejo Nacional de Investigaciones Científicas y Técnicas com sede no Instituto de Historia Argentina y Americana "Dr. Emilio Ravignani”, UBA/CONICET. Doutor Honoris Causa pela Universidad Nacional del Centro de la Provincia de Buenos Aires, pela Universidad Nacional de Salta e pela Universidad de Concepción del Uruguay. Diretor da coleção de História Argentina e Americana da Editoria Sudamericana. Professor visitante na Universidade Hebraica de Jerusalém (Israel) e no Departamento de Estudios Españoles y Latinoamericanos (1988). Docente de pós-graduação no Seminário de Doutorado da Faculdade de Filosofia e Letras da UBA (1990, 1991, 1992) e no Seminário de Doutorado do Instituto Universitario Ortega y Gasset (Madrid, 1993). Diretor de Estudos Convidado na École des Hautes Études en Sciences Sociales (Paris, 1994). Conferencista em reconhecidas universidades argentinas e internacionais, inclusive no Brasil. Diretor do Instituto de Historia Argentina y Americana "Dr. Emilio Ravignani" da Faculdade de Filosofia e Letras da UBA (1986-2012). Mais informações sobre a vida e a obra deste autor, ver: https://es.wikipedia.org/wiki/Jos\%C3\%A9 Carlos Chiaramonte
} 


\section{KEYWORDS}

Hispanic-American Constitutionalism. Ancient constitution. Anarchic caudillismo.

\section{SUMÁRIO}

1. Introdução. 2. O constitucionalismo limitado às constituições escritas. 3. O constitucionalismo antigo em autores europeus. 4. $\mathrm{O}$ antigo constitucionalismo europeu em autores espanhóis. 5. O antigo constitucionalismo como limite do poder. 6. A antiga Constituição na América hispânica. 7. A antiga Constituição e as ditaduras. 8. Conclusão. Referências. Dados da publicação.

\section{INTRODUÇÃO}

Este artigo ${ }^{* * *}$ não é um texto de história constitucional, mas uma análise do que o reconhecimento da existência de uma antiga constituição ${ }^{* * * *}$ nas sociedades hispanoamericanas antes da aparição das constituições escritas implica, problema crucial para a compreensão da história política hispano-americana do século XIX. Embora trate em sua maior parte da história do Rio da Prata, muitas das observações contidas neste texto concernem também à história de outros países hispano-americanos.

Advertir que a partir de suas independências os povos hispano-americanos, embora não contassem com constituições escritas, não por isso careciam de normas constitucionais, é algo que ainda encontra resistências. Por isso, entendo que uma análise dessa natureza contribuiria para eliminar as confusões sobre as normas políticas existentes antes do surgimento das constituições escritas e, particularmente, sobre um dos fenômenos dominantes da história política do século XIX hispano-americano, a ditadura - então chamada de faculdades extraordinárias (“facultades extraordinarias”) -, e sua relação com as ditaduras que abundaram no século XX.

\section{O CONSTITUCIONALISMO LIMITADO ÀS CONSTITUIÇÕES ESCRITAS}

Ocorre frequentemente que constitucionalistas e historiadores venham a datar o começo do constitucionalismo com a aparição das primeiras constituições escritas, desde o final do século XVIII. Esse critério - que existe não somente na historiografia europeia, mas também na latino-americana - é notoriamente anti-histórico, possivelmente efeito de uma projeção anacrônica ao passado de critérios correspondentes ao positivismo jurídico.

\footnotetext{
*** Quero agradecer à valiosa colaboração da Dra. Nora Souto, tanto por seu trabalho na localização de fontes como por suas observações ao rascunho do texto.

***** Nota de tradução: ao longo da tradução, o termo "constituição" foi assim grafado, em letras minúsculas, acompanhando o uso do autor deste texto. Ademais, a totalidade das citações no corpo do texto, em forma recuada ou não e que estavam tanto em espanhol antigo como moderno, foram traduzidas ao português pelos tradutores.
} 
Um politólogo como Giovanni Sartori reconhece a difusão do conceito de constituição no século XVIII, porém menospreza seu uso por não se ajustar ao novo conteúdo "garantista" que define. Ou seja, utiliza o termo antigo para designar o novo conceito, porém desvalorizando o uso original. ${ }^{1}$ Assim, escreve distinguindo os dois usos do termo constituição de forma valorativamente diversa:

Seja como for, o fato continua sendo o de que hoje 'constituição' converteuse em termo utilizado com dois significados totalmente diferentes: um significado específico e substantivo (o significado garantista) e um significado cósmico e formal. No primeiro deles, 'constituição' é o ordenamento protetor das liberdades do cidadão. No segundo, 'constituição' é qualquer forma que um Estado dê a si mesmo. ${ }^{2}$

Ao escrever a Sartori, em resposta ao envio de um ensaio sobre constitucionalismo, Norberto Bobbio criticou essa forma de enfocar o termo "constituição":

(...) o uso do termo 'Constituição' em sentido não neutro, isto é, para referirse apenas às constituições que preferimos, é enganoso. Todos os Estados têm uma Constituição, pelo simples fato de que todos os Estados têm uma norma fundamental. (....) Se o abandono da neutralidade científica conduz a chamar de constituições apenas as boas, deixe-me dizer que seguiu o caminho errado e, desta vez, ensejado o sinal de perigo. ${ }^{3}$

Por outro lado, afirmar a superioridade das constituições escritas por seu conteúdo garantista não leva em consideração que as antigas constituições se fundavam em noções do direito natural, das quais um dos traços politicamente mais relevantes era o propósito de impor limites ao poder real, evitando os abusos do príncipe em prejuízo de seus súditos, abusos que o converteriam em tirano. ${ }^{4}$

\footnotetext{
${ }^{1}$ SARTORI, Giovanni. Capítulo 1: Constitución. In: Elementos de teoría política. Madrid: Alianza, 1992, p. 13 et seq.

${ }^{2}$ SARTORI, Giovanni. Capítulo 1: Constitución. In: Elementos de teoría política. Madrid: Alianza, 1992, p. 19.

${ }^{3}$ BOBBIO, Norberto. [Carta de Norberto Bobbio a Nicola Matteucci]. Destinatário: Nicola Matteucci. Breuil, 25 jul. 1963. Trad. de Raúl Gustavo Ferreyra e Vannesa Alejandra Pérez Rosales. Revista Derechos en Acción: ReDeA, a. 2, n. 3, p. 321, 2017. [Nota de tradução: Disponível em https://revistas.unlp.edu.ar/ReDeA/issue/view/349. Acesso em 15 dez. 2020].

${ }^{4} \mathrm{Na}$ baixa Idade Média, “(...) el derecho natural, lejos de constituir un mero referente extrínseco a la realidad, actuaba ordenándola desde dentro convirtiéndose de esta manera en un verdadero límite a la potestad del príncipe y, en general, al ejercicio del cualquier poder político o doméstico" - GARCÍA PÉREZ, Rafael. Antes leyes que reyes: Cultura jurídica y constitución política en la edad moderna (Navarra, 1512-1808). Milano: Giuffre, 2008, p. 68 .
} 
Um critério acertado sobre o que a palavra constituição implica, encontramo-lo em outro politólogo contemporâneo, Nicola Matteucci:

(...) A constituição, com efeito, é a própria estrutura de uma comunidade política organizada, aquela ordem necessária que deriva da designação de um poder soberano e dos órgãos que o exercem. (...) Para o jurista, todos os Estados - e assim tanto os Estados absolutistas do século XVII como os totalitários do século XX - têm uma constituição, na medida em que sempre há, tácita ou expressamente, uma norma base que atribui a potestade soberana de império. ${ }^{5}$

Na negação da pertinência do vocábulo constituição, temos que um vocábulo já em uso adiantado no século XVIII é considerado impróprio por não se ajustar ao conceito de constituição difundido durante os séculos XIX e XX; nesse sentido, relativo a constituições que possuem outras e distintivas características, entre elas a de provir de um poder constituinte, a de conformar um documento escrito, a de conter normas para assegurar a vigência dos direitos individuais e a de estabelecer mecanismos para o controle dessas normas.

Cabe aclarar que nem sempre se trata de uma impugnação explícita, mas simplesmente da omissão do caráter constitucional das antigas leis fundamentais, tal como se lê em uma popular enciclopédia, nem sempre confiável, que resume os critérios em voga sobre o ponto:

Uma constituição (...) é um texto codificado de caráter jurídico-político, surgido de um poder constituinte, que tem o propósito de constituir a separação de poderes, definindo e criando os poderes constituídos (legislativo, executivo e judiciário) (...) ademais, é a lei fundamental de um Estado, com nível superior ao restante das normas jurídicas, fundamentando (segundo o normativismo) todo o ordenamento jurídico (....) ${ }^{6}$

O peculiar dessa postura é que não só conserva um vocábulo antigo modificando seu sentido senão que, ademais, implicitamente anula ou menospreza a validade do uso para o qual foi cunhado, isto é, para designar as antigas normas de direito público que, em sua época, às vezes recebiam o qualificativo de constituição e, em outras, de leis fundamentais, ou ainda, simplesmente, de leis.

Para melhor compreender as características desse desacordo, convém examinar as características do vocabulário constitucional existente já no século XVIIII, pois o uso da palavra

\footnotetext{
${ }^{5}$ MATTEUCCI, Nicola. Constitucionalismo. In: BOBBIO, Norberto; MATTEUCCI, Nicola. Diccionario de Política, A-J. 4ª ed. México: Siglo Veintiuno, 1985. p. 335.

6 CONSTITUCIÓN. In: Wikipedia: a enciclopédia livre. [Nota de tradução: Disponível em https://es.wikipedia.org/wiki/Constitución. Acesso em 16 dez. 2020].
} 
constituição para designar as normas que regiam, no mínimo, as sociedades do século XVIIII não é criação de historiadores posteriores, mas dos próprios contemporâneos. Por tal razão, parece-me conveniente observar alguns dos usos dos vocábulos "constituição" e "leis fundamentais" nos autores que mais influíram nos processos de independência dos séculos XVIII e XIX.

\section{O CONSTITUCIONALISMO ANTIGO EM AUTORES EUROPEUS}

Em primeiro lugar, se não queremos limitar o uso do termo constituição aos textos escritos, há de se notar a pluralidade de seus significados, apreciável em três tipos distintos de referências. Uma, à organização de um Estado; outra, ao conjunto de leis, escritas ou não, e de tradições, que governam a conduta privada e pública dos membros do Estado; por último, ao texto escrito que define essas normas. Poderíamos agregar outra característica que as constituições escritas latino-americanas trouxeram com elas, qual seja, a função de inaugurar ou reafirmar o caráter de Estado independente daqueles para os quais foram feitas. Por último, também é de notar a relação fluida do vocábulo constituição com a expressão "leis fundamentais" - em certas ocasiões, relação de sinonímia; em outras, expressão de conceitos diferentes.

Contudo, por razões que de imediato explicarei, merece ser previamente destacado um comentário sobre o significado do termo “constituição' efetuado há muitos anos por P. PradierFodéré em suas notas a um famoso manual de direito das gentes, o de Vattel, na edição francesa de $1863::^{7}$

O termo constituição, em seu sentido etimológico, expressa a maneira de ser, o modo segundo o qual uma coisa está organizada. Desde esse ponto de vista, pode-se dizer que não há sociedade sem constituição, dado que a sociedade supõe a ordem, a organização. Na linguagem política, dá-se o nome de constituição ao conjunto de regras que determinam a maneira pela qual uma nação deve ser governada: é a lei que fixa a distribuição dos poderes. Essas regras

\footnotetext{
${ }^{7}$ VATTEL. Le droit des gens ou principes de la loi naturelle appliqués a la conduite et aux affaires des nations et des souveraines. Paris: Librairie de Guillaumin et Cie., 1863 ( $1^{\mathrm{a}}$ ed., 1758), 3 v. A respeito de outros aspectos do pensamento constitucional de Vattel, assim como de suas coincidências e diferenças em relação a outros teóricos da época, ver: MALASPINA, Elisabetta Fiocchi. L'eterno ritorno del Droit des gens, di Emmer de Vattel (secc. XVIII-XIX): L'impatto sulla cultura giuridica in prospettiva globale. Frankfurt am Main: Max Planck Institute for European Legal History, 2017. p. 90-101.
} 
podem não ser escritas (...). Enfim, por figura de linguagem, chama-se de constituição o escrito que contém essa lei. ${ }^{8}$ (grifo nosso)

Além da clareza com que explica o uso da palavra constituição, quero ressaltar a última frase desse parágrafo, na qual se conceitua como resultado de uma "figura de linguagem" o uso hoje prevalecente reservado ao termo para designar um documento escrito. Antigamente, "constituição" era sinônimo de organização e, por sua vez, do conjunto de normas, escritas ou não, que regiam um país; depois, o termo passou a designar o escrito que as define. Trata-se de um comentário, o de Pradier-Fodéré, que mostra o vínculo substantivo entre uma e outra forma de constituição como relativas à organização política de um país, mas que, ademais, testemunha a natureza distinta do sentido original do termo e o "artifício" de sua utilização para designar os textos constitucionais escritos.

O recém mencionado Vattel, em seu famoso tratado sobre o direito das gentes, no parágrafo 27 do capítulo III, "Da Constituição do Estado, dos deveres e dos direitos da Nação sob esse aspecto", sustentava que:

A regra fundamental que determina a maneira com que se deve exercer a autoridade pública é o que forma a constituição do Estado; nela se vê sob qual forma a Nação atua como corpo político, como e por quem deve ser governado o povo, quais são os direitos e quais os deveres dos governantes. No fundo, essa constituição não é outra coisa senão o estabelecimento da ordem na qual a Nação se propõe a trabalhar em conjunto para obter as vantagens às quais se direciona o estabelecimento da sociedade política. ${ }^{9}$

Vattel foi o difusor da obra de Christian Wolff, que também se ocupou da constituição e das leis fundamentais:

A Constituição do governo ou do Estado é a determinação da maneira pela qual se deve alcançar o objetivo da sociedade civil. Para poder conhecer os direitos contidos no império civil, os deveres dos que governam tanto como

\footnotetext{
${ }^{8}$ PRADIER-FODÉRÉ, P. Nota. In: VATTEL. Op. Cit., p. 153 e 154: "Le mot constitution, pris dans le sens étymologique, exprime la manière d'être, le mode suivant lequel une chose est organisée. A ce point de vue, l'on peut dire qu'il n'y a pas de société sans constitution, puisque la société suppose l'ordre, l'organisation. Dans le langage politique, on donne le nom de constitution à l'ensemble des règles qui déterminent la manière dont une nation doit être gouvernée: c'est la loi qui fixe la distribution de pouvoirs. Ces règles peuvent être non-écrites; elles ont même dû l'être dans le principe; il est certain qu'il avait une constitution en France avant 1789. Enfin par figure de langage, on appelle constitution l'écrit que renferme cette loi”.

${ }^{9}$ VATTEL. El Derecho de Gentes, o principios de la Ley Natural, aplicados a la conducta, y a los negocios de las naciones y de los soberanos. Traduzida ao espanhol, corrigida e aumentada nessa impressão com uma notícia da vida do autor pelo Licenciado Don Manuel María Pascual Hernández. Tomo I. Madrid: [s.n.], 1834. p. 31. Na edição original: VATTEL. Le droit des gens..., Op. Cit., vol. I, cap. III, “De la constitution de l'état...”, p. 153 et seq.
} 
dos que obedecem, e os direitos de cada um, é a razão pela qual há que se tratar aqui da constituição do Estado.

E remete a um parágrafo anterior no qual escreve que "as leis pelas quais se limita o exercício do poder se denominam fundamentais (...) o Príncipe está obrigado a observar as leis fundamentais e não pode mudá-las por sua vontade". ${ }^{10}$

Assim como Vattel é considerado difusor de Wolff, por sua vez Barbeyrac e Burlamaqui o são da obra de Pufendorf. Assim, J. J. Burlamaqui, de muita influência não somente em países da Europa como também no processo da independência norte-americana, empregava tanto a expressão "leis fundamentais" como o termo "constituição" para referir-se à conformação política das Nações. ${ }^{11}$ Burlamaqui, que nisso seguia Pufendorf, ${ }^{12}$ no título $4^{\circ}$, "Das leis fundamentais", explicava que:

As Leis fundamentais do Estado, consideradas em toda sua extensão, não são somente as ordenações pelas quais o corpo inteiro da Nação determina qual deve ser a forma do Governo, e como será feita a sucessão da Coroa, mas também o são as convenções entre o povo e aquele ou aqueles aos quais se transfere a Soberania, que regulam a maneira pela qual se deve governar, e pelas quais se estabelecem os limites da autoridade soberana.

E agregava: "Esses regulamentos são chamados de leis fundamentais, porque são como a base e o fundamento do Estado, sobre as quais é erigido o edifício do Governo, e que os povos consideram como o que proporcionam toda a força e segurança". ${ }^{13}$

\footnotetext{
${ }^{10}$ Traduzimos esses e os parágrafos seguintes do tomo V, capítulo III, De la Constitution du gouvernement, ou de l'État, § MXVII, p. 389 e § DCCCCLXXXIV, p. 327 (1 $1^{\text {a }}$ edição em latim, 1750) de Christian Wolff: "La Constitution du gouvernement ou de l'État, c'est la détermination de la manière dont on doit parvenir au but de la société civile. C'est pourquoi pour qu'on puisse connoître les droits renfermés dans l'empire civil, les devoirs tant de ceux que commandent, que de ceux qui obéissent, \& les droits de chacun, il faut traiter ici de la constitution de l'État"; e "Les Loix par lesquelles l'excercice de l'empire est restreint son appelées fondamentales (...) le Prince est obligé d'observer les loix fondamentales, et qu'il ne peut les changer à son gré” (WOLFF, Christian L. B. de. Institutions du Droit de la Nature et des Gens. 6 tomos. Leide: [s.n.], MDCCLXXII).

${ }^{11}$ Recordemos que, para muitos autores da época, Nação e Estado eram sinônimos. Nesse sentido, ver: CHIARAMONTE, José Carlos. Nación y Estado en Iberoamérica: El lenguaje político en tiempos de las independencias. Buenos Aires: Sudamericana, 2004. p. 35.

${ }^{12}$ Sobre as leis fundamentais em Pufendorf, conferir: PUFENDORF, Samuel. Le droit de la nature et des gens, ou systeme general des principes les plus inportans de la morale, de la jurisprudence, et de la politique. Traduzido do latim por Jean Barbeyrac. $6^{\text {a }}$ ed. Basilea: [s.n.], 1750 - 2 tomos, liv. VII, cap. VI, § X, p. 369 et seq.

${ }^{13}$ Traduzimos esses e os parágrafos seguintes de: BURLAMAQUI, J. J. Principes du Droit Politique. Tomo I. Amsterdam: Chez Zacharie Chatelain, 1751 - parte I, capítulo VII, título $3^{\circ}$, § XXXV e título $4^{\circ}$, § XXXVI, p. 7576: "Les Loix fondamentales de l'Etat, prises dans toute leur étendue, sont non seulement des ordonnances par lesquelles le corps entier de la Nation détermine quelle doit être la forme du Gouvernement, et comment on succédera à la Couronne, mais encore ce sont des conventions entre le peuple et celui ou ceux à qui il défère la Souveraineté, qui règlent la manière dont on doit gouverner, et par lesquelles on met des bornes à l'autorité souveraine"; e "Ces règlements sont appelés des loix fondamentales, parce qu'elles sont comme la base et le
} 
Porém, a partir do primeiro capítulo da segunda parte dessa obra, o vocábulo mais frequente é o de "constituição", tal como se observa neste parágrafo: "Há, portanto, diversas formas de Governo, segundo os diferentes sujeitos nos quais reside imediatamente a Soberania, e que pertencem ou a uma só pessoa ou a uma só assembleia, mais ou menos compostas: é isso o que faz a constituição do Estado".

Entre outras numerosas ocorrências do termo, também se observa nesta referência à conduta dos príncipes: "É necessário que um Príncipe se dedique com toda a aplicação possível a conhecer bem a constituição do Estado (...)". ${ }^{14}$

É de advertir, por outro lado, que a distinção constituição antiga/constituição moderna, como duas espécies incompatíveis, não é historicamente real, dado que normas antigas costumam seguir vigentes junto aos textos constitucionais. Assim, em recentes debates constitucionais norte-americanos, observou-se que a constituição da Filadélfia não era a única fonte constitucional válida, senão que, o que existe é um sistema constitucional composto por essa constituição escrita e pautas da "unwritten constitution" (constituição não escrita) ainda vigentes. ${ }^{15}$ E, da mesma forma, não é demasiado recordar que o art. 33 da atual constituição argentina invoca direitos não contidos na letra da constituição: “As declarações, direitos e garantias que a Constituição enumera não serão entendidos como negação de outros direitos e garantias não enumerados, mas que nascem do princípio da soberania do povo e da forma republicana de governo".

Como explicávamos em trabalhos anteriores, o conteúdo das antigas constituições não é tornado preciso facilmente, tal como ocorre no caso da constituição britânica, um dos mais frequentemente aludidos como exemplo desse tipo de constituição. A esse respeito, é de se recordar uma observação do famoso jurista e historiador britânico James Bryce, que, ao referirse às dificuldades de interpretação que costumam afligir o uso do termo "constituição", observava que elas não afetam “(...) o emprego da palavra em si, toda vez que tal palavra é

fondement de l'Etat, sur lesquelles l'édifice du Gouvernement est élevé, et que les peuples les considèrent comme ce qui en fait toute la force et la sûreté".

14 "Il y a donc diverses formes de Gouvernement, selon les différents sujets dans lesquels la Souveraineté réside immédiatement, et qu'elle appartient ou a une seule personne ou à une seule assemblée, plus ou moins composée: et c'est ce que fait la constitution de l'Etat"; e "Il faut qu'un Prince s'attache avec toute l'application possible à bien connoître la constitution de l'Etat (...)" (BURLAMAQUI, J. J. Op. cit., parte II, capítulo I, "Des diverses formes du Gouvernement", e capítulo VIII, "Des devoirs des Souverains, § III e § IX, p. 95 e 187).

${ }^{15}$ AMAR, Akhil Reed. Americas's Unwritten Constitution. New York, N.Y.: Basic Books, 2012. Veja-se, a título de exemplo, deste autor: “The phrases 'separation of powers', 'checks and balances', and 'the rule of law' are also absent from the written Constitution, but all these things are part of America's working constitutional system -part of America's unwritten Constitution". 
indispensável. A coisa existe e, portanto, deve haver um nome para designá-la”. E acrescentava, referindo-se às modalidades das antigas constituições:

Uma coisa não é menos real porque seus limites não podem ser definidos rigorosamente. Uma colina é uma colina e uma planície é uma planície, ainda que não possamos determinar o ponto em que a colina se transforma em planície. O conglomerado de leis e costumes por meio dos quais e sob os quais a vida de um Estado transcorre pode ser chamado com toda propriedade de sua Constituição. ${ }^{16}$

No processo da independência estadunidense é frequente encontrar referências a uma constituição não escrita cujo conteúdo também era difícil de precisar. Na heterogênea compreensão desse conceito - costumes, normas prescritas pelo poder legislativo, ou um corpo de princípios imutáveis mais além do alcance de uma instituição governamental - sobressaía sua também variada relação com o direito britânico tradicional conhecido como common law e, sobretudo, com o direito natural. Assim, um historiador norte-americano sustenta que ao se falar de uma constituição consuetudinária não se deveria confundir "consuetudinária" com "não escrita", pois, além de o costume e a prática serem fontes centrais de autoridade para as Constituições dos séculos XVII e XVIII, também existia uma variedade de materiais escritos. Entre essas fontes escritas, incluía-se a Magna Carta, a Bíblia e leis-chave como a Declaração de Direitos de 1689 (Bill of Rights) e o Ato de Estabelecimento de 1701 (Act of Settlement), bem como tratados de autores proeminentes, particularmente os de Vattel, Pufendorf e Grócio, e trabalhos filosóficos, entre os quais se destacavam os de John Locke. ${ }^{17}$

\section{O ANTIGO CONSTITUCIONALISMO EUROPEU EM AUTORES ESPANHÓIS}

Quanto ao antigo constitucionalismo espanhol, cabe destacar que o Diccionario de Autoridades, primeira edição do dicionário da Real Academia Española, já recolhia o uso do vocábulo constituição em seu segundo tomo, de 1729, definindo-o da seguinte maneira: "Ordenança, estabelecimento, estatuto, regras que são feitas e formadas para o bom governo e direção de uma República ou Comunidade". Assegurar “o bom governo”, uma expressão antiga

\footnotetext{
${ }^{16}$ BRYCE, James. Constituciones flexibles y constituciones rígidas. Madrid: Centro de Estudios Constitucionales, 1988. p. 6 et seq.

${ }^{17}$ KRAMER, Larry D. In Substance and in Principle, the Same as It Was Heretofore. The Customary Constitution. In: KRAMER, Larry D. The People Themselves. Popular Constitutionalism and Judicial Review. Oxford; New York: Oxford University Press, 2004. p. 10-13.
} 
que se utilizava para referir-se ao governo do príncipe em benefício de seus súditos, conformado, entre outras, às normas próprias do direito natural. Esse é o sentido então já vigente e que corresponde a expressões como "antiga constituição". ${ }^{18}$ É também mais um indicador de que, em tempos anteriores ao auge das constituições escritas, existiam na Espanha normas constitucionais que regiam a vida de reinos e de repúblicas.

Como exemplo, encontramos outros testemunhos no Manifesto da Suprema Junta Gubernativa de outubro de 1808, atribuído a Floridablanca, no qual constam referências a "nossas antigas leis constitutivas" e "às leis fundamentais da monarquia". ${ }^{19}$ Da mesma forma, há registro das expressões "leis constitucionais" e "constituição" em Jovellanos. Na Instrucción de la Junta de Legislación, de 1809, que leva sua assinatura, recomenda-se a necessidade de:

(...) meditar as melhoras que possa receber nossa Legislação, tanto nas leis fundamentais como nas positivas do Reino, e propor os meios para assegurar sua observância. (...) A Junta deverá, portanto, reunir todas as leis constitucionais de Espanha, considerando como tais quantas se refiram: $1^{\circ}$ aos direitos do Soberano, $2^{\circ}$ aos da Nação considerada como corpo social, $3^{\circ}$ a seus indivíduos considerados como membros e partes constituintes da sociedade espanhola.

E, refletindo a preocupação com a multiplicidade constitucional da monarquia, na sequência o escrito adverte que

Como nenhuma constituição política pode ser boa se lhe faltar unidade, e nada seja mais contrário a essa unidade que as várias constituições municipais e privilegiadas de alguns pueblos e províncias que são partes constituintes do corpo social, posto que elas tornam desiguais as obrigações e os direitos dos cidadãos, e reconcentrando seu patriotismo no pequeno círculo de seus distritos debilitam outro tanto seu influxo em relação ao bem geral da Pátria, a Junta de legislação investigará e proporá os meios para melhorar nossa legislação nesse aspecto, buscando a mais perfeita uniformidade, assim no governo

\footnotetext{
${ }^{18} \mathrm{E}$, também, à unwritten constitution utilizada na historiografia anglo-saxã. Veja-se, por exemplo: GREY, Thomas C. Origins of the Unwritten Constitution: Fundamental Law in American Revolutionary Thought. Stanford Law Review, v. 30, p. 843 et seq., maio 1978.

${ }^{19}$ FLORIDABLANCA. Primer Manifiesto de la Suprema Junta Gubernativa del Reino a la Nación Española. In: Obras originales del Conde de Floridablanca, y escritos referentes a su persona. Biblioteca de Autores Españoles. Organização de Antonio Ferrer del Río. Madrid: M. Rivadeneyra, 1867. p. 511 e 512. Para os significados de "leis fundamentais" na história espanhola, é útil consultar: VARELA SUANZES-CARPEGNA, Joaquín. La teoría del Estado en las Cortes de Cádiz. Orígenes del constitucionalismo hispánico. Madrid: Centro de Estudios Políticos y Constitucionales, 2011.
} 
interior dos pueblos e províncias como nas obrigações e direitos de seus habitantes. ${ }^{20}$

Em outro documento, assinado por Jovellanos e outros funcionários, o "Dictamen de la Comisión de Cortes que acompañó a las convocatorias por estamentos", de 8 de janeiro de 1810, constam referências à "antiga Constituição espanhola", bem como outros enunciados semelhantes, tais como "nossa constituição", "a constituição do Reino", "nossas leis fundamentais", "nossas antigas instituições e formas constitucionais", "caráter constitucional da Monarquia espanhola", "Constituição monárquica", "antigos direitos do povo", entre outras. Tratavase de decidir se a representação nas Cortes deveria ser de caráter individual ou estamental, forma esta defendida pelo Dictamen como própria de um Estado monárquico e que não prevaleceria nas Cortes de Cádiz.

Todavia, esse léxico constitucional já havia sido utilizado por Jovellanos muitos anos antes, no discurso que proferiu por ocasião de seu ingresso na Real Academia de História, no qual faz referência ao que chama de "a antiga constituição" e utiliza outras expressões similares, como "antiga legislação", "antigas leis", "a constituição e costumes coetâneos", "costumes e direito não escrito" ou, simplesmente, "leis" - tal como quando se refere às leis que recaíam "sobre objetos relativos ao direito público e à política superior do reino".

Nós, senhores, nos governamos hoje por leis feitas não só nos tempos mais remotos de nossa monarquia, mas também nas épocas que correm desde sua fundação até o presente. $\mathrm{O}$ código, que tem em nossos tribunais a primeira autoridade, é uma coleção de leis antigas e modernas, no qual, ao lado do mais recentemente estabelecido, estão consignados, ou melhor, confundidos, o que dispôs a mais remota antiguidade. ${ }^{21}$

Cabe esclarecer que essas expressões não são meros giros retóricos sem correspondência histórica, visto que nos escritos referentes à forma de convocar as Cortes são mencionadas diversas normas constitucionais da história política espanhola. Neles são invocados a antiga forma de eleição dos integrantes das Cortes, os antigos direitos do povo à eleição de seus

\footnotetext{
20 JOVELLANOS, Gaspar M. de. Instrucción de la Junta de Legislación (finales de septiembre de 1809). In: Obras completas. Tomo XI (Escritos políticos). Oviedo: Instituto Feijoo de Estudios del Siglo XVIII / Ayuntamiento de Gijón / KRK Ediciones, 2006. p. 266-267.

21 JOVELLANOS, Gaspar M. de. Discurso leído por el autor en su recepción a la Real Academia de la Historia, sobre la necesidad de unir al estudio de la legislación el de nuestra historia y antigüedades. In: Obras publicadas e inéditas. Biblioteca de Autores Españoles, v. 46. Organização de D. Candido Nocedal. Madrid: M. Rivadeneyra, 1963. p. 289. A palavra "constituição" possui 35 ocorrências nesse texto, sempre no sentido de antiga constituição. A referência a direito público e política superior do reino encontra-se na p. 200.
} 
representantes, assim como os das cidades, a antiga organização do governo municipal, cujos membros eram "tutores constitucionais de seus direitos", e são formulados conselhos sobre a forma e instituição da Representação nacional para as Cortes sucessivas, e para determinar a de cada um de seus Estamentos, apoiando-se, entre outras normas, na "célebre lei de Partida que regula esta matéria" e que "segundo esta lei, a instituição do Governo pertence às Cortes, e que estas Cortes devem ser compostas de todos os maiores do Reino, assim como os Prelados e os homens ricos, e outros homens bons e honrados das vilas".

O Dictamen aconselha respeitar as normas da antiga constituição do Reino, como a de "Que os Prelados em exercício e os grandes proprietários do reino sejam convocados às Cortes individualmente e segundo a antiga forma que indicam as cópias anexas"; e "Que um e outro Estamento, ora reunido ao Congresso geral, ora separado dele, devem sempre votar por ordem e não por cabeças, segundo o direito antigo e o costume incontroverso". ${ }^{22}$

Essas e muitas outras expressões sobre as normas constitucionais que regiam na Espanha mostram a utilização difundida desse conceito, mas também que não eram expressões meramente retóricas, senão referências a normas constitucionais reais. Por último, é de destacar que o autor mais influente em matéria de direito romano na Espanha do século XVIII, J. G. Heineccius, referia-se assim às leis fundamentais, ressaltando seu caráter obrigatório não só aos súditos como também ao rei:

Finalmente, uma vez definida a forma de governo, não resta já ao povo - para que forme uma república perfeita - senão eleger uma ou mais pessoas para que o governem, e prescrever-lhes certas regras para o mando, expressandoas em um decreto anterior, às quais então se dá o nome de lei fundamental, chamando-se assim aquelas coisas que se preveem por pacto, leis. Por conseguinte, a [lei] fundamental obriga igualmente o depositário do poder, seja ele um ou muitos, assim como os cidadãos, e daí vem que se diga que nada de bom pode ser feito em falta a essa lei fundamental da república ou reunião comum da cidade. ${ }^{23}$

\footnotetext{
${ }^{22}$ DICTAMEN de la Comisión de Cortes que acompañó a las convocatorias por estamentos ( 8 de enero de 1810). España. Junta Suprema Central (1808-1810), e RESOLUCIÓN de la Junta Central sobre la convocatoria por estamentos (21 de enero de 1810). España. Junta Suprema Central (1808-1810). Madrid, Imp. de los Hijos de J. A. García, 1885; ambos disponíveis na Biblioteca Virtual Miguel de Cervantes, 2004.

${ }^{23}$ HEINECCIO, [Johann Gottlieb]. Elementos del derecho natural y de gentes (...). Tomo II, Derecho de gentes. Madrid: [s.n.], 1837. A primeira edição, em latim, é da primeira metade do século XVIII: HEINECCIUS, Johann Gottlieb. Elementa juris naturae et gentium. Halle: [s.n.], 1738.
} 


\section{O ANTIGO CONSTITUCIONALISMO COMO LIMITE DO PODER}

O propósito de analisar o sentido da expressão "antiga constituição" obrigou-nos a revisar alguns exemplos dos usos dos conceitos de constituição e leis fundamentais a partir do século XVIII, bem como seu caráter de referência a realidades e não só de artifício retórico. Entretanto, não se compreenderia a natureza das antigas constituições se não nos ocupássemos de pôr de manifesto sua função básica de normas limitadoras da conduta dos governantes para evitar seu possível declínio em tirania. Comprovamo-lo com as palavras de Burlamaqui, que não faziam mais do que reiterar um critério comum em sua época: as normas "que restringem a autoridade soberana, que lhe dão limites, são chamadas de Leis Fundamentais do Estado" (“qui restreignent l'autorité souveraine, qui lui donnent des bornes, sont appelées Loix fondamentales de l'Etat"). O mesmo ponto pode ser comprovado lendo-se os comentários que tanto Wolff, Pufendorf, Vattel, Burlamaqui e Heineccius escreveram ao tratar desses conceitos.

Da mesma forma lemos em um trabalho sobre o antigo direito político espanhol, que esclarece algo sobre o que já havia chamado a atenção Vicens Vives: ${ }^{24}$

Certamente a qualificação de uma monarquia como absolutista habitualmente não pressupõe a negação de qualquer tipo de limite ao poder real. Já faz tempo que a historiografia deixou bem claro que o termo absoluto, em sua acepção originária aplicada ao poder do rei, implicava sua desvinculação da lei ditada por ele mesmo, mas não de outras exigências igualmente jurídicas, como eram os direitos fundados diretamente no direito natural, os iura naturalia. ${ }^{25}$

Como exemplo, a segunda lei da Primera Partida de Alfonso o Sábio, do século XIII, dado o caráter fundamental do direito natural e das gentes, já procedia a defini-los:

Ius naturale quer dizer em [língua] romance como direito natural tem para si os homens e até os outros animais com sentidos. Outrossim, ius gentium em latim quer dizer como direito comum a todos, o qual convém a todos os homens e não aos outros animais, porque os homens não poderiam viver entre si em paz, se não usassem dele (...).

E a Lei 10 da Segunda Partida explica que "tirano quer dizer como senhor cruel que se apoderou de algum reino ou terra pela força ou pelo engano ou por traição (...)". ${ }^{26}$ Porém, para

\footnotetext{
${ }^{24}$ VICENS VIVES, Jaime. Estructura administrativa estatal en los siglos XVI y XVIII. In: Coyuntura económica y reformismo burgués, y otros estudios de historia de España. Barcelona: Ariel, 1968. p. 104 et seq. ${ }^{25}$ GARCÍA PÉREZ, Rafael. Op. Cit., p. 22.

${ }^{26}$ Utilizamos o texto das Partidas disponível em https://www.biblioteca.org.ar/libros/130949.pdf.
} 
aquele que possuísse o reino com base em direito justo, se "usasse mal de seu poder, nas maneiras que dissemos nesta lei", "podem as pessoas dizer-lhe tirano e o senhorio que era de direito torna-se deturpado (...)”. Como é sabido, a função limitadora do poder do príncipe se estendia ao direito de resistência contra a tirania e até mesmo, para alguns teólogos jesuítas, à legitimação do tiranicídio. ${ }^{27}$

\section{A ANTIGA CONSTITUIÇÃO NA AMÉRICA HISPÂNICA}

Não é meu propósito, como já esclareci, ocupar-me da análise de questões constitucionais, mas sim estudar o efeito de algumas dessas questões durante o século XIX. Nesse sentido, é de advertir-se que essa postura, que provocou uma notória falta de percepção das normas que regiam os povos hispano-americanos nos tempos das independências, antes da aparição das constituições escritas, deu vez, com esse aparente vazio jurídico, à interpretação hipertrofiada do papel desempenhado pelos caudilhos e à cunhagem do conceito de caudilhismo, denominação imprópria do sistema político.

Segunda uma síntese da história constitucional latino-americana, o constitucionalismo recém começaria com a primeira constituição escrita, a venezuelana de 1811. Entre ela e a relativamente recente da Colômbia, de 1991, houve mais de duzentos textos constitucionais, muitos poucos deles duradouros. Das constituições latino-americanas que tiveram certa duração, nesse lapso contam-se apenas treze. Dessas, três provêm da primeira metade do século XIX, nove da segunda metade e tão somente uma do século XX. ${ }^{28}$

Se isso assim fosse, se a história constitucional se limitasse às constituições escritas, caberia perguntar-se como as sociedades hispano-americanas teriam conseguido funcionar durante os tempos anteriores à sua cunhagem ou nos intervalos entre elas. Por isso, há alguns anos, quando encontrei o enunciado "lei fundamental de nosso sistema", em um documento de 1811 enviado de Jujuy pelo canônico Juan Ignacio Gorriti à Junta de Buenos Aires, e "antiga constituição", no rascunho da resposta a Gorriti pelo Deão Funes, membro da Junta, bem como em um dos artigos do regulamento da Junta, de fevereiro de 1811, que estabelecia juntas

\footnotetext{
${ }^{27}$ MARIANA, Juan de. Del Rey y de la Institución de la Dignidad Real. Buenos Aires: Partenón, 1945. p. 134 (edição original: De rege et regis institutione, 1599): "No piensen, pues, los príncipes que están menos sujetos a sus leyes que lo están la nobleza y el pueblo a aquellas que hubiesen sancionado en virtud de su facultad, especialmente cuando hay muchas leyes que no san sido dadas por los príncipes, sino instituidas por la voluntad de toda la república, cuya autoridad e imperio es mayor que la del príncipe (...)”.

${ }^{28}$ BRAVO LIRA, Bernardo. El Estado constitucional en Hispanoamérica. 1811-1991. México: Escuela Libre de Derecho, 1992. p. 10 et seq.
} 
provinciais, comecei a intuir o que depois veio a se tornar mais claro para mim. Tratava-se da percepção de que os povos platinos não haviam estado subsumidos na anarquia política depois de iniciado o movimento de independência, mas estavam sujeitos às normas do antigo direito público espanhol, pouco modificadas caso se excetuasse a mudança no titular da soberania e algumas poucas medidas causadas pela recente alteração do estado político. ${ }^{29}$

Esse não era um critério compartilhado pela maioria dos historiadores, talvez influídos pela denúncia de Mariano Moreno em 1810, lamentando a falta de leis justas, abominando as das Índias e afirmando, num juízo que já refletia a influência das constituições escritas, que “(...) não temos constituição e sem ela é quimérica a felicidade que nos seja prometida (...)”.30 Essa perspectiva se encontraria claramente expressa há algumas décadas em um texto do historiador britânico John Lynch: “A paz perpetuou as estruturas da guerra e conduziu à aparição de um processo dualista na América hispânica: por um lado, deu-se o constitucionalismo e, por outro, o caudilhismo". ${ }^{31}$ Um critério semelhante informa o título que Emilio Ravignani escolheu colocar em um texto seu, "Inconstitución y régimen de pactos", ao tratar da situação das províncias platinas após o Congresso Constituinte de $1824 .{ }^{32}$

No entanto, o panorama constitucional dos povos platinos não era o da ausência de normas constitucionais, nem o da submissão a um regime de despotismo caudilhista, por mais que existissem episódios dessa índole. Pelo contrário, era o da continuação do antigo direito espanhol - privado e público - e sua colisão com os novos textos constitucionais escritos, que buscavam implantar um regime representativo com divisão de poderes em uma realidade pouco propícia para tais inovações. Recordemos que o processo aberto pelas independências implicou a adoção de projetos políticos tais como o do sistema representativo com divisão de poderes que haviam sido elaborados em distintos contextos constitucionais, particularmente nos das excolônias inglesas. O esforço por implantá-los gerou conflitos que frequentemente seriam considerados como manifestações de anarquia, atribuídas à resistência de caudilhos que, ao ascenderem ao poder, teriam gerado um vácuo constitucional. Uma forma distinta de interpretar a

\footnotetext{
${ }^{29}$ Veja-se meu livro: CHIARAMONTE, José Carlos. Ciudades, provincias, Estados: Orígenes de la nación argentina (1800-1846). Buenos Aires: Ariel, 1997; Idem. $2^{\text {a }}$ ed. Buenos Aires: Emecé, 2007; e a tradução ao português: CHIARAMONTE. Cidades, Províncias, Estados: Origens da Nação Argentina (1800-1846). São Paulo: Hucitec, 2009. A referência à antiga Constituição na primeira edição encontra-se nas p. 159 et seq.

${ }^{30}$ MORENO, Mariano. Escritos. $2^{\text {a }}$ ed. 2 v. Buenos Aires: Estrada, s.d. p. 230-231.

${ }^{31}$ LYNCH, John. Caudillos en Hispanoamérica, 1800-1850. Madrid: Mapfre, 1993. p. 119.

32 RAVIGNANI, Emilio. El Congreso nacional de 1824-1827. La Convención nacional de 1828-1829. Inconstitución y régimen de pactos. In: ACADEMIA NACIONAL DE LA HISTORIA. Historia de la Nación Argentina. v. VII (Desde el Congreso General Constituyente de 1824 hasta Rosas, seção I). $3^{\text {a }}$ ed. Buenos Aires: [s.n.], s.d.
} 
gênese desses conflitos é considerar que as inovações políticas se chocaram com normas políticas provenientes da antiga constituição de raiz hispânica.

Uma das primeiras evidências da antiga constituição nos povos hispano-americanos foi a forma de legitimar a constituição de juntas de governo mediante a afirmação da soberania do povo e a invocação do pacto de sujeição e seu corolário da retomada da soberania. Dali para diante, o curso dos acontecimentos seguiu regido pela antiga constituição, mais as tentativas de reforma política. No Rio da Prata, o Regulamento provisório ditado pelo Congresso de Tucumán para as Provincias Unidas de Sudamérica, de 3 de dezembro de 1817 - documento frequentemente invocado no Rio da Prata como norma constitucional nos anos posteriores -, em sua seção II, Do poder legislativo, capítulo I, art. II, expressava claramente as características gerais da antiga constituição e o caráter das modificações que começava a sofrer, tudo sujeito à possível adoção de uma nova constituição que se considerava iminente, mas que não se obteria até 1853:

Até que a constituição determine o conveniente, subsistirão todos os códigos legislativos, cédulas, regulamentos e demais disposições gerais, e particulares, do antigo governo Espanhol que não estejam em oposição direta ou indireta com a liberdade e independência destas Províncias, nem com este Regulamento e demais disposições que não sejam contrárias a ele, expedidas desde vinte e cinco de maio de mil oitocentos e dez.

Tratava-se de um conjunto constitucional ao qual teria de se agregar algo não mencionado nesse texto: o direito consuetudinário.

A falta de reconhecimento da existência de um regime de legalidade como o que existe em toda sociedade organizada indica-nos que o dilema de Sarmiento - civilização ou barbárie - continua tendo certo eco em nossa historiografia. É por isso estranho, por exemplo, que do famoso texto de Alberdi, as Bases..., se descuide a transcendência do que ali escreveu sobre esse aspecto particular:

(...) nós mesmos temos leis de direito público e privado que contam com séculos de existência. No século XIV [sic] promulgaram-se as Leyes de Partidas, que regeram nossos povos americanos desde sua fundação, e também são seculares nossas Leis das Índias e nossas Ordenanças de comércio e de navegação. Recordemos que, a nosso modo, tivemos um direito público antigo. (...) Durante a revolução, modificamos mil vezes os governos, porque as leis não eram observadas. Porém, nem por isso demos por insubsistentes e nulas as 
Siete Partidas, as Leis das Índias, as Ordenanças de Bilbao etc. Confirmamos implicitamente essas leis, pedindo aos novos governos que as cumprissem. ${ }^{33}$

Os testemunhos sobre a consciência de existir uma antiga constituição na América hispânica também são abundantes. Já mencionamos o uso desse conceito no Rio da Prata até 1811. Também cabe recordar textos como o famoso Memorial de Agravios, de 1809, redigido pelo neogranadino Camilo Torres: "Que negócio mais árduo que o da defesa do reino e do soberano, a reforma do governo e a restituição da monarquia a suas bases primitivas e constitucionais, cujo transtorno causou os males que hoje experimentamos?". 34

Contudo, por sua eloquência, sobressaem os textos do famoso novo-hispano Frei Servando Teresa de Mier, que sustentava a existência de uma "constituição americana", a qual teria sido pactuada com a monarquia espanhola desde antigamente. ${ }^{35}$ Assim, em sua história da revolução novo-hispânica, encontram-se expressões como constituição, antiga constituição, leis fundamentais, constituição americana e Magna Carta (americana). Frei Servando faz referência, por exemplo, à “constituição que os reis deram à América" ou à "antiga" constituição que modificaram os deputados europeus que integraram as Cortes de Cádiz. O modelo para os americanos - escrevia Frei Servando desde a Inglaterra - “(...) enquanto o permitam as circunstâncias, deve ser a constituição desta nação bem-aventurada de onde escrevo, e onde se encontra a verdadeira liberdade, segurança e propriedade. (...) Não a encontrareis escrita como comédia em cenas: estas pertencem ao gênio leve e cômico dos franceses (...)".

E, reafirmando sua visão elogiosa de uma constituição não escrita, observava: "Os povos nunca se governaram senão por usos, prescrições e leis". ${ }^{36}$ Por isso,

(...) certamente não pediríamos que se mudasse a antiga constituição da monarquia, mas que se a melhorasse; não que se arrancassem as leis fundamentais, nem que se destruíssem todas as nossas (...). Em uma palavra: não

\footnotetext{
${ }^{33}$ ALBERDI, J. B. Bases y puntos de partida para la organización política de la República Argentina. $7^{\mathrm{a}}$ ed. Buenos Aires: Plus Ultra, 1994. p. 259.

${ }^{34} \mathrm{O}$ Memorial de Agravios é o nome pelo qual se conhece a Representação do Cabildo de Bogotá, capital do Novo Reino de Granada, encaminhada à Suprema Junta Central de Espanha, no ano de 1809, escrita por José Camilo de Torres.

${ }^{35}$ Sobre o uso do termo Constituição no México colonial, ver o parágrafo "2. La antigua constitución", em: VILLORO, Luis. El proceso ideológico de la Revolución de Independencia. $3^{\mathrm{a}}$. ed. México DF: UNAM, 1981. p. 47. Assim: "Se trataría, pues, de un amplio movimiento de retorno a una tradición, que se quiere liberal, anterior al absolutismo; este movimiento - aún no estudiado, por desgracia, en su unidad - presentaría diferentes aspectos en distintos países del mundo hispánico" (VILLORO, Luis. Op. cit., p. 51, nota).

${ }^{36}$ MIER, Fray Servando Teresa de. Historia de la revolución de la Nueva España. Edição crítica. Coordenação de André Saint-Lu e Marie-Cécile Bénassy-Berling. Paris: Publications de La Sorbonne, 1990. liv. XIV, p. 619.
} 
exigiríamos senão que a política dos que governam estivesse de acordo com as leis, ou estas com a constituição com a qual os reis concordaram com nossos pais. ${ }^{37}$

Da mesma forma, em suas Memorias..., nas quais afirma que "a coroa de Espanha é constitucionalmente eletiva" e alude às "guerras dos comuneros para sustentar a Constituição da Espanha", Frei Servando menciona em numerosas oportunidades as normas constitucionais espanholas. $^{38}$

\section{A ANTIGA CONSTITUIÇÃO E AS DITADURAS}

Uma característica da história hispano-americana, em consonância com antiga constituição, é a frequência do uso dos poderes de exceção, isto é, as ditaduras. De acordo com as normas políticas da época, a ditadura podia ser um recurso legítimo, enquanto o que hoje chamamos ditadura então recebia o nome de tirania. ${ }^{39}$ Trata-se de um critério que já se registra em Maquiavel e também em autores de direito romano. Maquiavel elogiava a ditadura romana como um recurso legítimo, quando fosse adotado pelo Senado, porém reprovava a usurpação do poder por algum cidadão que se apropriasse de uma "autoridade extraordinária". ${ }^{40} \mathrm{E}$ tratadistas de direito romano, sem adotar a distinção de Maquiavel, admitiam a legitimidade dos recursos extraordinários. ${ }^{41}$

Por exemplo, é um traço pouco notado, em que pese sua significação, que, a partir de 1810, os povos platinos viveram a maior parte dos anos seguintes em regime de ditadura, então denominada de "faculdades extraordinárias". Poucas vezes se aponta que quando apareceram

\footnotetext{
${ }^{37}$ MIER, Fray Servando Teresa de. Op. cit., p. 525.

${ }^{38}$ MIER, Fray Servando Teresa de. Memorias. Tomo II. 2a ed. México: Porrúa, 1971. p. 332, 357 e 362-368, entre outras.

${ }^{39}$ Ver a respeito meu artigo: CHIARAMONTE, José Carlos. Facultades extraordinarias y antigua constitución en los Estados rioplatenses del siglo XIX. Respuesta a Alejandro Agüero. Mundo Nuevo, Nuevos Mundos, Débats, 2018. Disponível em: http://journals.openedition.org/nuevomundo/74801.

${ }^{40}$ MACHIAVELLI, Niccolò. Discorsi sopra la prima Deca di Tito Livio. v. 1. Milano: [s.n.], 1821. cap. XXXIV, p. 101: "L'autorità dittatoria fece bene e non danno alla Repubblica romana, e come le autorità che i cittadini si tolgono, non quelle che sono loro dai suffragi liberi date, sono alla vita civile perniziose".

${ }^{41}$ Os tratadistas de direito romano abordavam o tema da ditadura como algo legítimo quando as circunstâncias a justificassem. A respeito, cf.: HEINECCIO, [Johann Gottlieb]. Elementos del derecho natural y de gentes... Madrid: [s.n.], 1837 - tomo II, Derecho de Gentes, cap. VIII, A "De los derechos permanentes de la soberanía y qué puede considerarse como justo acerca de ésta”, CLXVIII, p. 133, e Cap. VII, CXXX, p. 103 e 105. Da mesma forma, ver: PUFENDORF, Samuel. Le droit de la nature et des gens... Tradução do latim ao francês de Jean Barbeyrac, Basilea. [s.n.], 1750 - tomo II, liv. VII, cap. VI A "Des caractères propres et des modifications de la Souveraineté”, p. 379, e, também, On the Duty of Man and Citizen According to Natural Law. Cambridge; New York: Cambridge University Press, 1991. p. 147.
} 
os primeiros textos constitucionais de muitos dos Estados "provinciais", ${ }^{42}$ que estabeleciam regimes representativos com divisão de poderes, estes deveriam constantemente dar passo às ditaduras. No caso de Buenos Aires, por exemplo - que, se bem carecia de um texto constitucional, não o era das chamadas leis fundamentais -, dos vinte e três anos que vão do primeiro governo de Juan Manuel de Rosas, iniciado em dezembro de 1829, à sua queda em 1852, viveu mais de vinte em regime de ditadura.

Adicionaria que esta composição de lugar também permitiria compreender melhor a história política do século XX, dominada pela frequência das distintas formas de ditadura até 1983. Porque, por efeito da influência de correntes historiográficas que destacam problemas particulares da história de países europeus e da dos Estados Unidos, na historiografia latinoamericanista priorizaram-se temáticas como a do republicanismo, do liberalismo ou da divisão de poderes. Trata-se, é certo, de problemas importantes, sobre os quais foram feitos trabalhos de valor. No entanto, não houve aprofundamento como merece nas raízes do principal fenômeno que dominou a história política do século XIX e que projetou sua influência sobre o século $\mathrm{XX}$, isto é, a ditadura, outra norma das antigas leis, que a legitimava como recurso para enfrentar situações extraordinárias.

A esse respeito, no concernente ao Rio da Prata, se bem o recurso à ditadura esteja presente desde a ação da Primeira Junta de Governo, em 1810, e desde então fosse admitida como recurso legítimo, ${ }^{43}$ merecem ser recordados muito especialmente os debates de 1830 e 1832 na Junta de Representantes de Buenos Aires sobre o projeto de renovação das faculdades extraordinárias a Rosas, um exemplo revelador de duas das principais características da história política do século XIX, tanto da continuidade do direito público espanhol como da impossibilidade de assentar o regime representativo com divisão de poderes devido ao frequente recurso à ditadura.

Apenas um poder ditatório [sic] [alegava um destacado político da época] pode reprimir no ato, com mão forte, as maquinações dos gênios perversos e agitadores (...). Um saudável terror completará a obra. (...) A ditadura, senhores, é uma das maiores pragas que afligiram e devastaram os estados livres.

\footnotetext{
${ }^{42}$ Analisei a impropriedade da denominação "províncias" em: CHIARAMONTE, José Carlos. El federalismo argentino en la primera mitad del siglo XIX. In: CARMAGNANI, Marcello. (Org.). Federalismos latinoamericanos: México/Brasil/Argentina. México: El Colegio de México/F.C.E., 1993 (2ª ed., 2011). p. 94 et seq.

${ }^{43}$ Vejam-se os encômios à ditadura, em 1812, no periódico Mártir o libre, escritos por Bernardo de Monteagudo: "Continúan las observaciones didácticas", "Concluyen las observaciones didácticas", e "Censura política". Mártir o libre, Buenos Aires, 29 mar., 6 abr. e 13 abr. 1812, respectivamente. In: MONTEAGUDO, Bernardo de. Escritos políticos. Biblioteca Virtual Universal, 2003.
} 
Bem sabemos. No entanto, às vezes ela é necessária para domar o espírito anarquizador. Repúblicas antigas e modernas, em seus piores momentos, recorreram a esta terrível, porém salutar medicina. ${ }^{44}$

Nesse debate, o deputado Sáenz Peña, um dos que se opunha à renovação das faculdades extraordinárias, afirmava:

(...) [a] administração da justiça deve ser feita por leis, sem dúvida, porém estas leis são precisamente as leis que antes formavam os códigos legislativos e pragmáticas, cédulas reais e demais disposições que regiam no antigo Governo espanhol (...) essas leis que foram ditadas por D. Fernando e Da. Isabel para oprimir-nos, essas leis são as que hoje nos regem, porque estão ordenadas a observar pelos corpos legislativos que nos presidiram (...). ${ }^{45}$

Outro deputado, Diego Alcorta, relevante figura intelectual da época e coautor do texto da Constituição portenha de 1833 - que nunca entrou em vigor - compartilhava o critério de Sáenz Peña quanto à vigência das antigas leis espanholas, modificadas em alguns pontos pelo regulamento de $1817 .{ }^{46} \mathrm{E}$ o deputado Olavarrieta - outra importante figura política portenha reafirmava essa vigência invocando a autoridade de Vattel: “(...) nossas instituições estão real e firmemente estabelecidas. Pergunta Watel [sic] se o P. L. [Poder Legislativo] pode derrogar as leis fundamentais, e, cabalmente, diz que não, porque tendo o P. L. sua autoridade e [existindo] leis fundamentais, não pode sobrepor-se a elas, nem as revogar". ${ }^{47}$

Outro dos membros da Junta de Representantes de Buenos Aires, em 1830, durante a discussão sobre as consequências nocivas das faculdades extraordinárias em relação aos direitos individuais, encarecia os "remédios que concedem as leis, e que não somente estão estabelecidos por leis positivas, mas que também é [sic] de direito natural". ${ }^{48}$ Em consonância com esse critério, outro deputado expunha a função primordial do direito natural nas leis fundamentais:

\footnotetext{
${ }^{44}$ Palavras de Pedro F. Cavia no Diario de Sesiones de la H. Junta de Representantes de la provincia de Buenos Aires, v. 11 (sessão do dia 23 jul. 1830). Ocupei-me desse debate em: CHIARAMONTE, José Carlos. La democracia representativa argentina: antecedentes históricos. In: HEREDIA, Mariana; PEREYRA, Sebastián; SVAMPA, Maristella. (Coord.). José Nun y las ciencias sociales. Aportes que perduran. Buenos Aires: Biblos, 2019.

${ }^{45}$ Palavras do deputado Sáenz Peña: Diario de Sesiones de la H. Junta de Representantes de la provincia de Buenos Aires, tomo 14, n. 281 (sessão de 26 out. 1832). [Disponível no Inst. Ravignani, copias mimeografiadas, tomo 15 , p. 14 e 19].

${ }^{46}$ Diario de Sesiones de la H. Junta de Representantes de la provincia de Buenos Aires, tomo 14, n. 282, (sessão de 29 out. 1832). [Disponível no Inst. Ravignani, copias mimeografiadas, tomo 15, p. 05].

${ }^{47}$ Diario de Sesiones de la H. Junta de Representantes de la provincia de Buenos Aires, tomo 14, n 283, (sessão de 5 nov. 1832). [Disponível no Inst. Ravignani, copias mimeografiadas, tomo 15, p. 08].

${ }^{48}$ Palavras do deputado Ugarteche no Diario de Sesiones de la H. Junta de Representantes de Buenos Aires (sessão de 7 jun. 1830). [Disponível no Archivo del Instituto Ravignani, copias mimeografiadas].
} 
As leis primordiais da sociedade pública estão fundadas no direito natural do homem: elas se encontram impressas no coração de todos e, por conseguinte, são inalienáveis. Uma lei espanhola, adotada por nós, e que hoje rege em nosso foro, justifica e corrobora esse princípio. Essa diz: Ninguém poderá doar todos os seus bens durante sua vida - do que se infere claramente que se a lei impede a um particular dispor de todos os seus bens, para que não fique insubsistente, com quão maior razão poder-se-ia dizer que são inalienáveis de modo permanente os primordiais e sagrados direitos do homem? ${ }^{49}$

Direitos que as faculdades extraordinárias anulariam. A luta de parte dos políticos portenhos na defesa do regime representativo como garantia dos direitos individuais, embora tenha obtido um triunfo momentâneo no rechaço à renovação das faculdades extraordinários em 1832, fracassaria poucos anos depois, em 1835, dado que se concedeu a Rosas a suma del poder público, a qual perduraria até sua queda.

Como podemos ver, distintos componentes da antiga constituição, conforme as circunstâncias, podiam sustentar posições antagônicas, a de instaurar uma ditadura para enfrentar graves riscos políticos, ou a de questionar a renúncia aos direitos naturais, considerados inalienáveis.

\section{CONCLUSÃO}

Quanto ao uso do termo "constituição" nos tempos das independências hispanoamericanas, podemos argumentar que se os contemporâneos o usavam para se referir às normas políticas vigentes nas ex-colônias espanholas, tal como vimos em casos como os do neogranadino Camilo Torres, do novo-hispano Frei Servando Teresa de Mier, dos rio-platenses Juan Ignacio Gorriti ou do Deão Funes, ou se, entre outros casos, um seguidor de Vattel como o primeiro reitor da Universidade de Buenos Aires, o padre Antonio Sáenz, o utilizava em seu texto para o ensino do direito natural e das gentes, ${ }^{50}$ é lógica sua pertinência para designar o ordenamento político dessas ex-colônias que se aprontavam para dar a si próprias constituições escritas, sem que a falta destas últimas pressupusesse a inexistência até então de uma ordem jurídica.

\footnotetext{
${ }^{49}$ Diario de Sesiones de la H. Junta de Representantes de la provincia de Buenos Aires, tomo 14, n. 283 (sessão de 5 nov. 1832). [Disponível no Inst. Ravignani, copias mimeografiadas, tomo 15, p. 20].

${ }^{50}$ SÁENZ, Antonio. Instituciones Elementales sobre el Derecho Natural y de Gentes. Curso dictado en la Universidad de Buenos Aires en los años 1822-23. Buenos Aires: Instituto de Historia del Derecho Argentino, Facultad de Derecho y Ciencias Sociales, 1939. p. 71, 83 et seq.
} 
Em síntese, não tem sido fácil para os historiadores latino-americanistas, e segue não o sendo, reconhecer a existência de uma ordem constitucional prévia às constituições escritas. $\mathrm{O}$ peso do velho esquema de um caudilhismo anárquico e o fato de que o termo "constituição" está demasiadamente associado aos textos escritos que conhecemos atualmente parecem dificultar a compreensão da existência de constituições não escritas - que, na realidade, geralmente costumavam ser reuniões de pautas consuetudinárias e de textos escritos. Chamem-nas de antiga constituição ou de leis fundamentais, o certo é que as sociedades hispano-americanas, como as anglo-americanas e as europeias, possuíam normas constitucionais, não isentas, é claro, de violações de magnitudes e frequências variadas - coisa, por outro lado, que afeta qualquer sistema político até os dias de hoje -, frequentemente produto de um conflito entre pautas da antiga constituição e a tentativa de inovações políticas incongruentes com aquelas.

É por essa razão que, aprofundando o significado do que acabo de explicar, devemos alertar para a impropriedade já comentada do conceito de caudilhismo, que temos empregado como se fosse a denominação de uma espécie de sistema político; um conceito, ademais, relativo a traços que podemos encontrar em qualquer sistema político. Foram as normas dessa constituição antiga as que orientavam as condutas dos governantes, inclusive a dos denominados "caudilhos", conduta que frequentemente se mal interpretou, catalogando-a como expressão de arbitrariedades personalistas, assimilando-as às violações das normas constitucionais, violações que existiram, é certo, como também existiriam durante a vigência de constituições escritas.

Em suma, creio que um enfoque dessa natureza também pode ser de utilidade para aprofundar as ainda vagas aproximações sobre as diferenças no êxito das democracias anglo-saxãs e das latinas. $\mathrm{O}$ condicionamento que algumas das antigas pautas constitucionais implicaram para as tentativas de replicar regimes representativos com divisão dos poderes não pode menos do que obstaculizar o enraizamento do que se costuma chamar de democracias representativas. Porque, transcorrido o século XIX, o século XX não deixou tudo isso para trás. Na Argentina, proibidas constitucionalmente as faculdades extraordinárias pela constituição de 1853 , a ditadura perdeu legitimidade sem por isso desaparecer da vida política, adotando diversas formas, entre as quais se destacam as ditaduras subsequentes aos golpes de Estado: a derrocada dos Presidentes Yrigoyen, em 1930; Castillo, em 1943; Perón, em 1955; Frondizi, em 1962; Illia, em 1966; e Isabel Perón, em 1976. Felizmente, desde 1983 as trocas de governo resultaram de processos eleitorais, embora a possibilidade de abuso dos decretos de necessidade e urgência continue sendo uma ameaça. 
Ainda que o uso do passado para explicar o presente costume produzir resultados pouco confiáveis, estou convencido de que uma reinterpretação do processo histórico aberto pelos movimentos de independência, para além de sua importância para esclarecer a história desse lapso do passado, também oferece algumas chaves para compreender o ocorrido até o presente, dado que os países latino-americanos nunca terminaram de enraizar adequadamente o regime representativo nem o federalismo, e dado que os sérios defeitos de nossas democracias continuam ainda à vista.

\section{REFERÊNCIAS}

ALBERDI, J. B. Bases y puntos de partida para la organización política de la República Argentina. $7^{\text {a }}$ ed. Buenos Aires: Plus Ultra, 1994.

AMAR, Akhil Reed. Americas's Unwritten Constitution. New York, N.Y.: Basic Books, 2012.

BOBBIO, Norberto. [Carta de Norberto Bobbio a Nicola Matteucci]. Destinatário: Nicola Matteucci. Breuil, 25 jul. 1963. Trad. de Raúl Gustavo Ferreyra e Vannesa Alejandra Pérez Rosales. Revista Derechos en Acción: ReDeA, a. 2, n. 3, p. 321, 2017. Disponível em https://revistas.unlp.edu.ar/ReDeA/issue/view/349.

BRAVO LIRA, Bernardo. El Estado constitucional en Hispanoamérica. 1811-1991. México: Escuela Libre de Derecho, 1992.

BRYCE, James. Constituciones flexibles y constituciones rígidas. Madrid: Centro de Estudios Constitucionales, 1988.

BURLAMAQUI, J. J. Principes du Droit Politique. Tomo I. Amsterdam: Chez Zacharie Chatelain, 1751.

CHIARAMONTE, José Carlos. Cidades, Províncias, Estados: Origens da Nação Argentina (1800-1846). São Paulo: Hucitec, 2009.

Ciudades, provincias, Estados: Orígenes de la nación argentina (1800-1846). Buenos Aires: Ariel, 1997 (2 ed. Buenos Aires: Emecé, 2007).

. El federalismo argentino en la primera mitad del siglo XIX. In: CARMAGNANI, Marcello. (Org.). Federalismos latinoamericanos: México/Brasil/Argentina. México: El Colegio de México/F.C.E., 1993 (2a ed., 2011).

Facultades extraordinarias y antigua constitución en los Estados rioplatenses del siglo XIX. Respuesta a Alejandro Agüero. Mundo Nuevo, Nuevos Mundos, Débats, 2018. Disponível em http://journals.openedition.org/nuevomundo/74801. 
La democracia representativa argentina: antecedentes históricos. In: HEREDIA, Mariana; PEREYRA, Sebastián; SVAMPA, Maristella. (Coord.). José Nun y las ciencias sociales. Aportes que perduran. Buenos Aires: Biblos, 2019.

. Nación y Estado en Iberoamérica: El lenguaje político en tiempos de las independencias. Buenos Aires: Sudamericana, 2004.

CONSTITUCIÓN. In: Wikipedia: a enciclopédia livre. Disponível em https://es.wikipedia.org/wiki/Constitución.

Diario de Sesiones de la H. Junta de Representantes de Buenos Aires (sessão de 7 jun. 1830). [Disponível no Archivo del Instituto Ravignani, copias mimeografiadas].

Diario de Sesiones de la H. Junta de Representantes de la provincia de Buenos Aires, v. 11 (sessão do dia 23 jul. 1830).

Diario de Sesiones de la H. Junta de Representantes de la provincia de Buenos Aires, tomo 14, n. 281 (sessão de 26 out. 1832). [Disponível no Instituto Ravignani, copias mimeografiadas, tomo 15].

Diario de Sesiones de la H. Junta de Representantes de la provincia de Buenos Aires, tomo 14, n. 282, (sessão de 29 out. 1832). [Disponível no Instituto Ravignani, copias mimeografiadas, tomo 15].

Diario de Sesiones de la H. Junta de Representantes de la provincia de Buenos Aires, tomo 14, n 283, (sessão de 5 nov. 1832). [Disponível no Instituto Ravignani, copias mimeografiadas, tomo 15.

DICTAMEN de la Comisión de Cortes que acompañó a las convocatorias por estamentos (8 de enero de 1810). España. Junta Suprema Central (1808-1810). Madrid, Imp. de los Hijos de J. A. García, 1885. Disponível na Biblioteca Virtual Miguel de Cervantes, 2004.

FLORIDABLANCA. Primer Manifiesto de la Suprema Junta Gubernativa del Reino a la Nación Española. In: . Obras originales del Conde de Floridablanca, y escritos referentes a su persona. Biblioteca de Autores Españoles. Organização de Antonio Ferrer del Río. Madrid: M. Rivadeneyra, 1867.

GARCÍA PÉREZ, Rafael. Antes leyes que reyes: Cultura jurídica y constitución política en la edad moderna (Navarra, 1512-1808). Milano: Giuffre, 2008.

GREY, Thomas C. Origins of the Unwritten Constitution: Fundamental Law in American Revolutionary Thought. Stanford Law Review, v. 30, mai. 1978.

HEINECCIO, [Johann Gottlieb]. Elementos del derecho natural y de gentes (...). Madrid: [s.n.], 1837.

HEINECCIUS, Johann Gottlieb. Elementa juris naturae et gentium. Halle: [s.n.], 1738. 
JOVELLANOS, Gaspar M. de. Discurso leído por el autor en su recepción a la Real Academia de la Historia, sobre la necesidad de unir al estudio de la legislación el de nuestra historia y antigüedades. In: . Obras publicadas e inéditas. Biblioteca de Autores Españoles, v. 46. Organização de D. Candido Nocedal. Madrid: M. Rivadeneyra, 1963.

JOVELLANOS, Gaspar M. de. Instrucción de la Junta de Legislación (finales de septiembre de 1809). In: . Obras completas. Oviedo: Instituto Feijoo de Estudios del Siglo XVIII/ Ayuntamiento de Gijón/KRK Ediciones, 2006.

KRAMER, Larry D. In Substance and in Principle, the Same as It Was Heretofore. The Customary Constitution. In: KRAMER, Larry D. The People Themselves. Popular Constitutionalism and Judicial Review. Oxford; New York: Oxford University Press, 2004.

LYNCH, John. Caudillos en Hispanoamérica, 1800-1850. Madrid: Mapfre, 1993.

MACHIAVELLI, Niccolò. Discorsi sopra la prima Deca di Tito Livio. Milano: [s.n.], 1821, v. 1.

MALASPINA, Elisabetta Fiocchi. L'eterno ritorno del Droit des gens, di Emmer de Vattel (secc. XVIII-XIX): L'impatto sulla cultura giuridica in prospettiva globale. Frankfurt am Main: Max Planck Institute for European Legal History, 2017.

MARIANA, Juan de. Del Rey y de la Institución de la Dignidad Real. Buenos Aires: Partenón, 1945.

MATTEUCCI, Nicola. Constitucionalismo. In: BOBBIO, Norberto; MATTEUCCI, Nicola. Diccionario de Política, A-J. 4ª ed. México: Siglo Veintiuno, 1985.

MIER, Fray Servando Teresa de. Historia de la revolución de la Nueva España. Edição crítica. Coordenação de André Saint-Lu e Marie-Cécile Bénassy-Berling. Paris: Publications de La Sorbonne, 1990.

MIER, Fray Servando Teresa de. Memorias. Tomo II. 2ª ed. México: Porrúa, 1971.

MONTEAGUDO, Bernardo de. Censura política. Mártir o libre, Buenos Aires, 13 abr. 1812. In: . Escritos políticos. Biblioteca Virtual Universal, 2003.

. Concluyen las observaciones didácticas. Mártir o libre, Buenos Aires, 6 abr. 1812. In: Escritos políticos. Biblioteca Virtual Universal, 2003.

. Continúan las observaciones didácticas. Mártir o libre, Buenos Aires, 29 mar. 1812. In: Escritos políticos. Biblioteca Virtual Universal, 2003.

MORENO, Mariano. Escritos. $2^{\mathrm{a}}$ ed. Buenos Aires: Estrada, s.f., 2 v.

PRADIER-FODÉRÉ, P. Nota. In: VATTEL. Le droit des gens ou principes de la loi naturelle appliqués a la conduite et aux affaires des nations et des souveraines. 3 v. Paris: Librairie de Guillaumin et Cie., 1863 ( $1^{\text {a }}$ ed., 1758). 
PUFENDORF, Samuel. Le droit de la nature et des gens, ou systeme general des principes les plus inportans de la morale, de la jurisprudence, et de la politique. Traduzido do latim por Jean Barbeyrac. 2 tomos. $6^{\mathrm{a}}$ ed. Basilea: [s.n.], 1750.

. On the Duty of Man and Citizen According to Natural Law. Cambridge; New York: Cambridge University Press, 1991.

RAVIGNANI, Emilio. El Congreso nacional de 1824-1827. La Convención nacional de 1828-1829. Inconstitución y régimen de pactos. In: ACADEMIA NACIONAL DE LA HISTORIA. Historia de la Nación Argentina, v. VII, Desde el Congreso General Constituyente de 1824 hasta Rosas, seção I. $3^{\text {a }}$ ed. Buenos Aires: [s.n.], s.d.

RESOLUCIÓN de la Junta Central sobre la convocatoria por estamentos ( 21 de enero de 1810). España. Junta Suprema Central (1808-1810). Madrid, Imp. de los Hijos de J. A. García, 1885. Disponível na Biblioteca Virtual Miguel de Cervantes, 2004.

SÁENZ, Antonio. Instituciones Elementales sobre el Derecho Natural y de Gentes. Curso dictado en la Universidad de Buenos Aires en los años 1822-23. Buenos Aires: Instituto de Historia del Derecho Argentino, Facultad de Derecho y Ciencias Sociales, 1939.

SARTORI, Giovanni. Capítulo 1: Constitución. In: . Elementos de teoría política. Madrid: Alianza, 1992.

Siete Partidas. Disponível em https://www.biblioteca.org.ar/libros/130949.pdf.

VARELA SUANZES-CARPEGNA, Joaquín. La teoría del Estado en las Cortes de Cádiz. Orígenes del constitucionalismo hispánico. Madrid: Centro de Estudios Políticos y Constitucionales, 2011.

VATTEL. El Derecho de Gentes, o principios de la Ley Natural, aplicados a la conducta, y a los negocios de las naciones y de los soberanos. Traduzida ao espanhol, corrigida e aumentada nessa impressão com uma notícia da vida do autor pelo Licenciado Don Manuel María Pascual Hernández. Tomo I. Madrid: [s.n.], 1834.

VATTEL. Le droit des gens ou principes de la loi naturelle appliqués a la conduite et aux affaires des nations et des souveraines. 3 v. Paris: Librairie de Guillaumin et Cie., 1863 (1 ${ }^{\mathrm{a}}$ ed., 1758).

VICENS VIVES, Jaime. Estructura administrativa estatal en los siglos XVI y XVIII. In: Coyuntura económica y reformismo burgués, y otros estudios de historia de España. Barcelona: Ariel, 1968.

VILLORO, Luis. El proceso ideológico de la Revolución de Independencia. $3^{\mathrm{a}}$. ed. México DF: UNAM,1981

WOLFF, Christian L. B. de. Institutions du Droit de la Nature et des Gens. Leide: [s.n.], s.d. 


\section{DADOS DA PUBLICAÇÃO}

Categoria: artigo de autor convidado.

Recebido em: 01/12/2020.

Aceito em: 02/12/2020. 


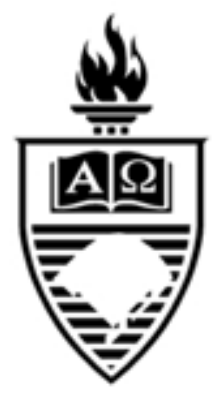

